\title{
Estuarine and Marine Geology (2011-2015)
}

\author{
V PURNACHANDRA RAO* and PARTHASARATHI CHAKRABORTY \\ CSIR-National Institute of Oceanography, Dona Paula 403 004, Goa, India
}

(Received on 17 May 2016; Accepted on 25 May 2016)

\begin{abstract}
The estuaries of the Mandovi and Zuari (Ma-Zu) Rivers and Godavari River have been investigated extensively for understanding the sedimentary and bio-geochemical processes during the last 5 years. Estuarine turbidity maximum is a characteristic feature at the mouth of Ma-Zu estuaries, formed by the interaction between tidal currents and river flows during monsoon, and by the re-suspension of bottom sediments by tidal and wind-induced currents during pre-monsoon. Kaolinite and illite, followed by minor goethite, gibbsite and chlorite are present in SPM and sediment of the estuaries. Smectite occurs in traces at river end stations but its contents increased downstream. The ${ }^{87} \mathrm{Sr} /{ }^{86} \mathrm{Sr}$ ratios of SPM are higher than those in hinterland rocks and laterite soil The $\mathrm{Nd}$ isotopic compositions of $\mathrm{Ma}-\mathrm{Zu}$ estuaries are influenced by the lateritization of source rocks and anthropogenic contribution of ore materials. The major and trace elements in sediments of $\mathrm{Ma}-\mathrm{Zu}$ estuaries indicate the metals contribution of metals from lateritic formations as well as iron ore. Shale-normalized REE patterns exhibit MREE- and HREE enrichment with positive Ce and Eu anomalies indicative of contamination from iron ore. Stable isotopes of organic matter indicate at least $\sim 20 \%$ terrestrial organic carbon (TOC) to the coastal system during wet season. Chemical speciations studies indicate that the concentrations of non-residual and dynamic metalsediment complexes (which are good indicators of bioavailability) of toxic metals gradually increase with increasing total metal loading in estuarine sediments. Quality and quantity of sedimentary organic matter (SOM) is one of the key factors which play a crucial role in controlling speciation of trace/toxic metal in sediments. The distribution and sources of particulate organic carbon and particulate nitrogen in 27 Indian estuaries during the monsoon indicate higher phytoplankton biomass with deeper photic zone than other estuaries receiving higher suspended matter. Detailed studies on rock-magnetic properties and $\delta^{13} \mathrm{C}_{\text {org }}$ in sediments off the Krishna-Godavari provide evidence of reductive diagenesis, formation of authigenic sulfides and occurrence of methane in these estuarine sediments and also episodic methane expulsion events.
\end{abstract}

Keywords: Estuarine Sedimentology; Anthropogenic Contamination; Metal-Sediment Interaction; Sedimentary Organic Matter; Reductive Diagenesis; Methane Formation

\section{Estuarine Sedimentology/Geochemistry}

Rivers are the dominant supplier of sediments to estuaries and adjacent seas. The transport and deposition of fine-grained, riverine sediments in estuaries are largelycontrolled by three factors: estuarine mixing, aggregation (flocculation), and primary particle properties. There are numerous small rivers globally bringing sediments into the estuaries and their sediment contribution to the adjacent seas is largely underestimated. Systematic seasonal studies were carried out on the concentrations and composition of suspended particulate matter (SPM) and bottom sediments along transect stations in two adjacent estuaries of minor rivers, i.e., the Mandovi-
Zuari(Ma-Zu) estuaries of western India (Fig. 1) to better understand the sediment dynamics, sedimentary and bio-geochemical processes, anthropogenic pollution and sediment contribution to the adjacent seas. The results on sedimentology and geochemistry of suspended and bottom sediments are given below:

\section{Suspended Sediment Dynamics in the Ma-Zu Estuaries}

Knowledge on the suspended sediment dynamics in the estuarine system has received considerable attention in recent years in response to the fact that the estuaries receive agricultural, industrial and domestic waste runoff from their watersheds. 


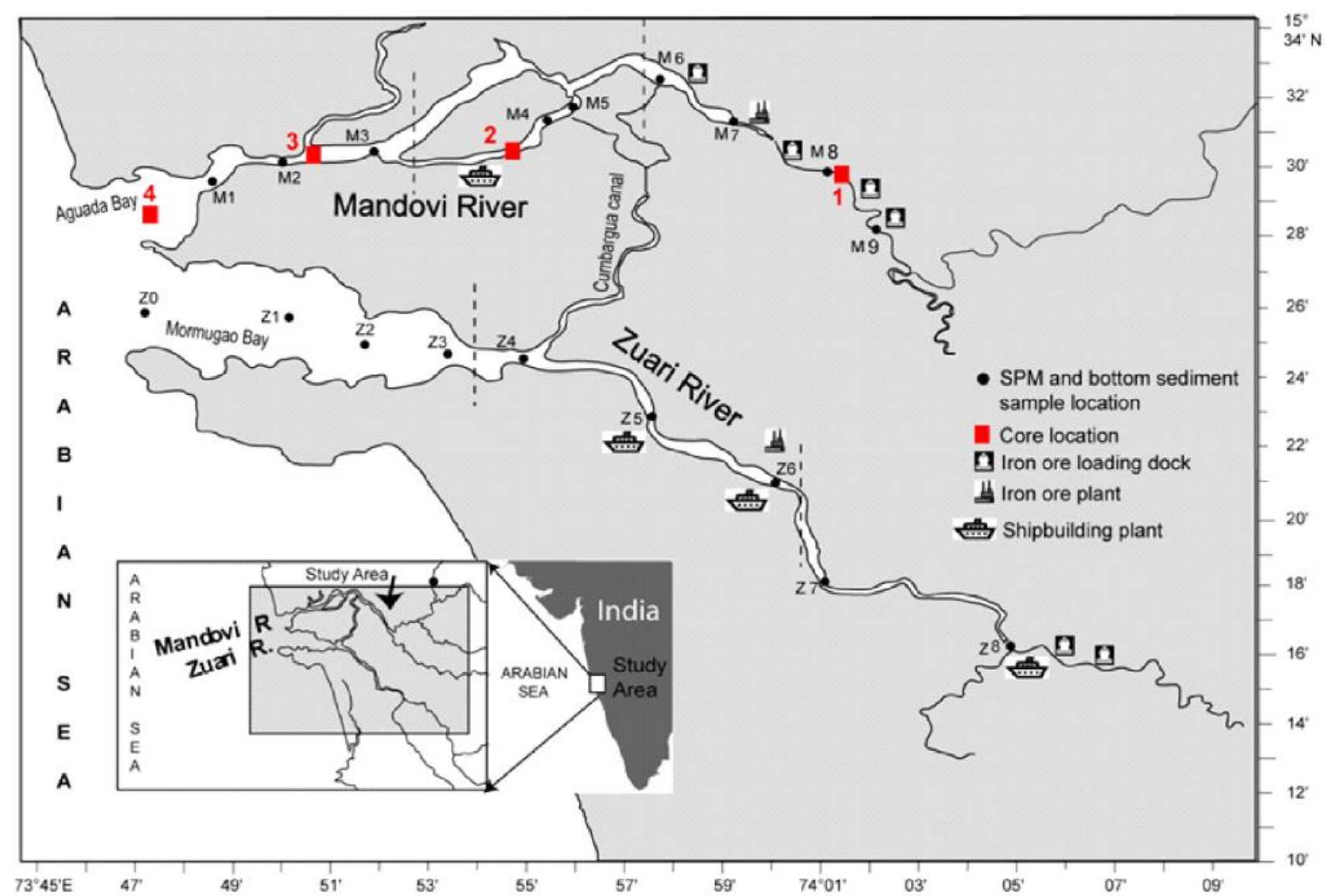

Fig. 1: Mandovi and Zuari estuaries, west coast of India

Dynamic estuarine processes control the distribution and transportation of suspended sediments. Understanding the suspended sediment movement on a seasonal scale is important for monitoring water quality, fate of pollutants, and for the success of dredging operations. Studies on the SPM collected along the transect stations in the Ma-Zuestuaries (Rao et al., 2011) indicate that the peaks of high SPM coincide with peaks of high rainfall and low salinity and also with peaks of moderate/low rainfall coupled with high salinity during the monsoon. The estuarine turbidity maximum (ETM) is a characteristic feature, it occurs in the channel accompanying spring tide during the monsoon and pre-monsoon, and shifts to the bay on neap tide during post-monsoon. ETM remains at the same position in the Mandovi River, both during the monsoon and pre-monsoon, whereas in Zuari it stretches upstream during monsoon and migrates seaward of the channel during pre-monsoon. The ETM coincides with the freshwater-seawater interface during the monsoon and is formed by the interaction between tidal currents and river flows. The ETM during pre-monsoon is associated with high salinities and is generated by tidal and wind-induced currents. The turbidity maximum on neap tide during post-monsoon may be due to the erosion and resuspension of sediments from the emergent tidal flats and transport of these turbid waters into the bay. Funneling effect of the narrowing bay in the Zuari estuary and associated physical processes effectively enhance the magnitude of the currents and transports sediments to the channel. SPM retention percentage indicates that the estuarine channel is prone tosiltation.Suja et al. (2016) studied the spatial distribution of SPM using laser in situ scattering and transmissometry (LISST-25X) and identified the zones of ETM in both the estuaries.

\section{Mineralogy and Sr-Nd Isotopes of SPM and Sediment in the Ma-Zu Estuaries}

The composition of clay minerals in estuarine sediments depends primarily on source rock, climate 
and topography of the drainage basin of the river. Clay minerals transported by the river to the sea are modified in estuaries by sedimentary processes. On the other hand, the $\mathrm{Sr}$ and $\mathrm{Nd}$ isotopic compositions of continental rocks depend on the $\mathrm{Rb} / \mathrm{Sr}$ and $\mathrm{Sm} / \mathrm{Nd}$ ratios and their ages. The $\mathrm{Sr}$ isotope signatures are excellent tracers for understanding processes such as water-rock interactions, the mixing of isotopically distinct water masses and the influence of geology on the composition of river water. Studies by Rao et al. (2014) on the clay minerals and Sr-Nd isotopes of SPM and sediment in the Ma-Zu estuaries indicate that the kaolinite and illite, followed by minor goethite, gibbsite and chlorite were present in SPM and sediment at all stations, both during monsoon and premonsoon. Smectite occurred in traces at river end stations but its content increased downstream in both the estuaries. Smectite contents was much higher in Zuari than in Mandovi estuary. The ${ }^{87} \mathrm{Sr} /{ }^{86} \mathrm{Sr}$ ratios and $€ \mathrm{Nd}$ of SPM were higher than those in hinterland rocks and laterite soils. The $\mathrm{Sr}$ ratios were highest at the river end stations of both the estuaries and decreased sharply seaward. The $\mathrm{Sm} / \mathrm{Nd}$ ratios of SPM and sediment were close to that of iron ore material flushed into the estuaries. The mean $€ \mathrm{Nd}$ of SPM and sediment were similar in both the estuaries. It is suggested that smectite is formed in coastal plains and its distribution downstream is controlled by lithology and drainage basin of rivers. Abundant kaolinite and high $\mathrm{Sr}$ ratios reflect chemical weathering and lateritization of source rocks. Sr isotopic ratios along the transects are influenced by changes in salinity, organic matter and turbidity. High and near identical $€ N d$ values along transect stations of both the estuaries suggest that the $\mathrm{Nd}$ isotopic compositions are influenced by the lateritization of source rocks and anthropogenic contribution of ore materials.

\section{Major and Trace Metals in the SPM and Sediments of the Ma-Zu Estuaries}

Suspended particulate matter (SPM) is an important carrier of various trace, nutrient, and pollutant elements and most of these elements are trapped within the estuaries and deposit in bottom sediments. Shynu et al. (2012) and Kessarkar et al. (2013) investigated the geochemistry of the SPM and sediments in the $\mathrm{Ma}-\mathrm{Zu}$ estuaries. The studies indicate that during the monsoon and pre-monsoon, the SPM increases, and the major and trace metals decreases from stations in the upstream to the downstream of the estuary. SPM is consistently low at all stations during the postmonsoon. Trace metals $(\mathrm{Cu}, \mathrm{Ni}, \mathrm{Zn}, \mathrm{Cr}$, and $\mathrm{Pb}$ ) show strong inter-relationships. They correlate well with $\mathrm{Fe}$ and $\mathrm{Mn}$ only during the monsoon. The concentrations of $\mathrm{Cr}, \mathrm{Cu}$, and $\mathrm{Pb}$ are high during the post-monsoon. Enrichment factors and $\mathrm{I}_{\text {geo }}$ values of metals indicate that $\mathrm{Mn}$ shows significant to strong pollution in all seasons, while $\mathrm{Cr}, \mathrm{Ni}$, and $\mathrm{Zn}$ during monsoon, and $\mathrm{Cr}$ during the post-monsoon show moderate pollution. The major and trace metals are governed seasonally by a combination of river discharge, resuspension, spillage of $\mathrm{Fe}-\mathrm{Mn}$ particulates, and anthropogenic contamination. Incursion of saline waters deep into the river channel during the dry season facilitates aggregation and settling of particulate-borne pollutants close to the discharge area, thereby keeping the estuarine waters free from major contamination. Particulates resuspended from the Zuari bay are dominated by ore dust, which are advected into the channels of both the estuaries during the lull periods of the monsoon.

Prajith et al. (2016) investigated the major elements and trace metals in four sediment cores recovered along a transect in the Mandovi estuary. The sediments were clayey silts in cores from the upper/lower estuary and sand-dominated in cores from the middle estuary/bay. Organic carbon (OC) content varied from 0.5 to $4 \%$, with higher values in fine grained sediments. The mean $\mathrm{Fe}$ and $\mathrm{Mn}$ contents of sediments from the upper/middle estuary were 3-5 times and 8-13 times, respectively higher than the reference sediment (RS) from the same estuary. The mean $\mathrm{Fe}$ and $\mathrm{Mn}$ contents of sediments from the lower estuary/bay were close to the RS. Strong inter-metal correlation among $\mathrm{Ti}, \mathrm{V}, \mathrm{Cr}$ and $\mathrm{Zr}$ in all the cores indicated their contribution from a common source, probably the laterites from hinterland. Trace metals were more enriched in fine-grained sediments than in sand dominated sediments. Early diagenetic control on the redistribution of metal is evident in core sediments from the middle estuary to Bay. The distribution of $\mathrm{Mo}, \mathrm{U}$ and $\mathrm{Pb}$ followed that of $\mathrm{Fe}$ and $\mathrm{Mn}$ in theupper estuary and OC in the lower estuary/ bay. The results indicated strong anthropogenic contribution of metals from ore deposits in the upper/ middle estuary. The Mn and $\mathrm{Cr}$ contents of sediment in the upper/middle estuary and $\mathrm{Fe}$ in the middle estuary were highly enriched suggestive of 'significant 
pollution signal'. More trace metals from the middle estuary were moderately enriched.

\section{REE and $Y$ in the SPM and Sediments of the Ma- $\mathrm{Zu}$ Estuaries}

Rare earth elements (REE) form a key group of trace elements whose properties change systematically and gradually across the series (from La to Lu). REE have been used as geochemical tracers to characterize igneous rocks of various types, determine detrital sediment sources and elucidate seawater circulation patterns, hydrothermal fluxes and past oxygenation of the oceans. REE transported through fluvial source are extensively modified in the estuaries before reaching the ocean. Investigations on the REE in SPM of estuarine water across a salinity gradient in the Mandovi estuary (Shynu et al., 2012) indicate that the mean total-REEs ( $\mathrm{REE}$ ) and light REE to heavy REE ratios are lower than that of the average suspended sediment in World Rivers and PostArchean average Australian shale. Although the $\Sigma$ REE broadly agree with SPM levels at each station, their seasonal distributions along transect are different. The mean REE decreased marginally seaward and was $<25 \%$ at the sea-end stations than at the riverend stations. Spatial variations in $\Sigma$ REE are maximum (64\%) during the pre-monsoon. Strong to moderate correlation of $\Sigma \mathrm{REE}$ with $\mathrm{Al}, \mathrm{Fe}$ and $\mathrm{Mn}$ in all seasons indicates adsorption and co-precipitation of REEs with alumino-silicate phases and $\mathrm{Fe}, \mathrm{Mn}$-oxyhydroxides. The middle REE- and heavy REE-enriched patterns

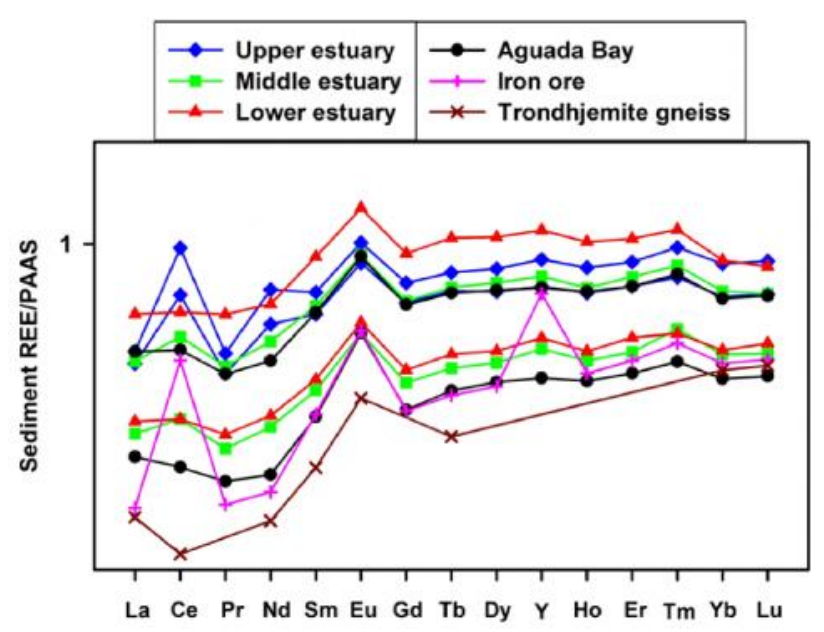

Fig. 2: PASS-normalized patterns of Rare earth elements (REE) and Yttrium (Y) in the sedments of the Mandovi estuary. REE pattern of iron ore is also shown with positive $\mathrm{Ce}$ and $\mathrm{Eu}$ anomalies are characteristic of the every station and season, both in SPM and sediment. They also exhibit tetrad effect with distinct third and fourth tetrads. Fe-Mn ore dust is the most dominant source for REEs. However, the seasonal changes in the supply of detrital silicates, Fe-Mn ore dust and particulates resuspended from bottom sediments diluted the overall effect of salinity on fractionation and distribution of REEs in the estuary.

Prajith et al. (2015a) investigated the mineralogy, major elements, rare earths and yttrium (REY) of bulk sediments in 4 gravity cores from the Mandovi estuary. The sediments of the upper/middle estuary showed abundant hematite, magnetite and goethite and high Fe, Mn, total-REE ( $\Sigma$ REE) and Y, while those in the lower estuary/bay showed abundant silicate minerals and relatively low Fe, Mn, $\Sigma$ REE and Y. $\Sigma$ REE showed significant correlation with clay and silt fractions and $\mathrm{Y}, \mathrm{Al}$ and organic carbon (OC) content of the sediments. The light to heavy REE ratios (LREE/HREE) of sediments were lower than in PAAS. The PAAS-normalized rare earths and yttrium (REY; Y inserted between Dy and Ho) patterns of sediments showed middle REE (MREE)and HREE-enrichment with positive Eu anomaly $(\mathrm{Eu} /$ $\mathrm{Eu}^{*}$ ) and variable $\mathrm{Ce}$ anomaly (Ce/Ce*) (Fig. 2). The REY of sediments is primarily controlled by its texture and REE of source sediment, which is ore materialdominated in the upper/middle estuary and silicate material-dominated in the lower estuary/bay. Low LREE/HREE ratios suggest that very fine-grained sediments were carried away from the estuary because of high-energy conditions. Fractionations of $\mathrm{REY}\left(\mathrm{Y} / \mathrm{Ho}, \mathrm{Sm} / \mathrm{Nd}, \mathrm{Ce} / \mathrm{Ce}^{*}\right.$ and $\left.\mathrm{Eu} / \mathrm{Eu}^{*}\right)$ are controlled by different mechanisms. High Y/Ho ratios in clayey silts are due to redistribution of Y and Ho by adsorption onto organic-rich, clays. Variations in $\mathrm{Sm} /$ $\mathrm{Nd}$ ratios are similar to that of $\mathrm{Eu} / \mathrm{Eu} *$ in the cores from the lower estuary/bay and are controlled by mineral constituents of the sediments. Positive $\mathrm{Ce}$ and Eu anomalies are inherited from ore material, and ore material and source rocks, respectively. Negative $\mathrm{Ce}$ anomaly is related to source rock material and influenced by La-enrichment at certain sediment intervals. The major elements and REE were investigated in 122 samples of SPM and 70 surficial sediments from the Zuari estuary and the adjacent shelf (Shynu et al., 2014). The distributions of mean $\Sigma \mathrm{REE}, \mathrm{Al}$ and $\mathrm{Fe}$ along the transect imitate each other 
and resemble inverted bowl-shaped pattern, with high and identical values at the lower estuary. The mean $\Sigma$ REE, $\mathrm{Al}$ and $\mathrm{Fe}$ of the sediment along the transect showed two peak high values, one in the upper estuary and another in the bay amid low values corresponding to the lower estuary. The variations in the mean ratio of $\Sigma \mathrm{REE}_{\mathrm{SPM}} / \Sigma \mathrm{REE}_{\mathrm{SED}}$ along transect resembled with the mean SPMat each station. The $\Sigma$ REE of sediments in shallow shelf were close to that of the bay and, decreased seaward with increasing depth. PAASnormalized REE patterns of every SPM/sediment sample revealed MREE- and HREE enrichment with positive $\mathrm{Ce}\left(\mathrm{Ce} / \mathrm{Ce}^{*}\right)$ and $\mathrm{Eu}\left(\mathrm{Eu} / \mathrm{Eu}^{*}\right)$ anomalies. $\mathrm{Ce} / \mathrm{Ce}^{*}$ was inversely correlated with $\mathrm{Eu} / \mathrm{Eu}^{*}$ and salinity and, directly correlated with Mn concentrations. The results indicate that the REE of SPM/sediment is dominated by Fe, Mn ore dust and, its distribution along transect is controlled by the estuarine turbidity maximum (ETM). The ETM and seasonal circulation in the estuary controlled mixing and advective transport of particulates to the shelf during monsoon and, into the estuary during dry season. This study indicates sediment contribution to the shelf from the tropical, minor rivers that are controlled by hydrodynamic conditions in the estuaries and should not be underestimated.

\section{Organic Matter in SPM and Sediments of the Ma- $\mathrm{Zu}$ Estuaries}

Run-off from the minor, tropical rivers is seasonal and, high during wet season (monsoon) and negligible during dry (non-monsoon) season. Circulation in the estuaries of these rivers is dominated by tidal and wind-driven currents during dry season. In view of the contrasting seasonal hydrodynamic conditions in the minor rivers, the river estuaries are expected to show low productivity during wet season and, autotrophic production and active biological and geochemical processes during dry season. Maya et al. (2011), Bardhan et al. (2015) and Shynu et al. (2015) investigated organic carbon (OC), total nitrogen (TN) and their isotopic compositions in SPM and surface sediment along the estuaries in the $\mathrm{Ma}-\mathrm{Zu}$ rivers. Unlike major rivers, SPM concentrations increases seaward with a general trend of decreasing particulate organic carbon (POC) in these rivers, mostly due to the presence of estuarine turbidity maximum (ETM) located downstream of the estuaries. POC and particulate nitrogen (PN) were higher in the Mandovi than in the Zuari estuary. Except during wet season in the Mandovi, POC/PN and $\delta^{15} \mathrm{~N}$ were altered by biogeochemical processes in both the estuaries and are not indicators of source organic matter. PN/POC and $\delta^{13} \mathrm{C}_{\text {org }}$ indicated the dominance of terrestrial plant-derived $\mathrm{OM}$ and terrestrial soilderived OM respectively, in the Mandovi and Zuari estuaries during wet season. The $\delta^{13} \mathrm{C}_{\text {org }}$ versus salinity plot indicated increasing proportions of marine $\mathrm{OM}$ seaward in both estuaries during dry season. OC and $\mathrm{TN}$ in the sediments of both estuaries were much lower than in the overlying suspended matter. The mean $\delta^{13} \mathrm{C}_{\text {org }}$ in the sediment and SPM were similar in both the seasons in Mandovi and only during wet season in Zuari estuary. Uniform mean values of ${ }^{13} \mathrm{C}_{\text {org }}$ in the lower estuary and bay of Zuari indicated efficient mixing of sediments during wet season. Sediments with relatively high $\delta^{13} \mathrm{C}_{\text {org }}$ and low $\delta^{15} \mathrm{~N}$ in the upper estuary of Zuari were related to anthropogenic contamination by sewage effluents during dry season. It is estimated that each river contributed at least $\sim 20 \%$ terrestrial organic carbon (TOC) to the coastal system during wet season and received similar quantity of TOC during dry season. Since there are more than 10,000 small rivers originating from monsoon-dominated and/or mountainous regions globally,it must be appreciated that their total TOC contribution to the coastal system must be substantial. Similar studies were conducted in Vaitarana estuary, Maharashtra by Volvoikar et al. (2014).

\section{Organic Matter (OM) in SPM and Sediments of the Godavari Estuary}

Sarma et al. (2012) investigated carbon and nitrogen content and their isotopic composition in SPM and sediments of the Godavari estuary and found significant variability in isotopic composition of $\mathrm{OM}$ over the entire length of the estuary. The mean isotopic ratios $\left(\delta^{13} \mathrm{C}_{\text {sed }}-25.1 \pm 0.9, \delta^{13} \mathrm{C}_{\text {sus }}-24.9 \pm 1, \delta^{15} \mathrm{~N}_{\text {sed }}\right.$ $8.0 \pm 2$ and $\delta^{15} \mathrm{~N}_{\text {sus }} 6.5 \pm 0.9 \%$ ) and elemental concentrations $\left(\mathrm{C}_{\text {sed }} 0.45 \pm 0.2 \%, \mathrm{C}_{\text {sus }} 0.9 \pm 0.7 \%\right.$, $\mathrm{N}_{\text {sed }} 0.07 \pm 0.05 \%$ and $\mathrm{N}_{\text {sus }} 0.16 \pm 0.1 \%$ ) support a predominantly terrigenous source. Significant enrichment in the isotopic ratios of $\delta^{13} \mathrm{C}$ from the upper to lower estuary in both suspended $(-27.5$ and $24.3 \%$, respectively) and sedimentary ( -26.2 and $24.9 \%$, respectively) phases indicates a decrease in the influence of terrigeneous material toward the mouth 
of the estuary. A significant positive relationship exists between the $\delta^{13} \mathrm{C}$ of suspended and sediment, which indicates that these two organic carbon pools are likely coupled in the form of a significant exchange between the two phases. A positive relationship exists between chlorophyll-a and suspended organic matter, which may mean that a significant source of organic carbon is the in situ produced phytoplankton. But applying a simple mixing model to the isotopes, data yielded about $46 \%$ as the contribution of the terrestrial source to suspended matter, which may support the excessive heterotrophic activity in the Godavari estuary reported earlier.

Krishna et al. (2015) reported the OM and its isotopic signatures in SPM and surface sediments of the Godavari estuary during no discharge period. The upper estuary is characterized by relatively high content of POC and Chl-a and low suspended matter and sediment OC. In contrast, the lower estuary is characterized by relatively low content of particulate OC and Chl-a and high suspended matter and sediment OC. Data and model results showed that the particulate $\mathrm{OM}$ is derived predominantly from freshwater phytoplankton in the upper $(\sim 85 \%)$ and lower $(\sim 0 \%)$ estuaries, with a minor contribution from estuarine phytoplankton ( $25 \%)$ and terrestrial C3 plants $(\sim 10 \%)$ in the lower estuary. On the other hand, sediment OM in the upper and lower estuaries derived from both autochthonous and allochthonous sources with nearly equal contributions. Although relatively high in situ production was observed in the upper than the lower estuary, relatively low sediment OC was found in the former than the latter region, suggesting that strong influence of preservation conditions rather than surface biological production on OC accumulation in sediments. This is attributed to intense transformation of OM by heterotrophs in the upper than the lower estuary because of prevailing conducive conditions for degradation of $\mathrm{OM}$ in the upper estuary during the study period.

The distribution and sources of POC and PN in 27 Indian estuaries during the monsoon indicates higher phytoplankton biomass in estuaries with deeper photic zone than other estuaries receiving higher suspended matter (Sarma et al., 2014). Relatively higher $\delta^{13} \mathrm{C}_{\mathrm{POC}}(-27.9$ to $-22.6 \%)$ and lower $\delta^{15} \mathrm{~N}_{\mathrm{PN}}(0.7$ to $5.8 \%$ ) were noticed in the estuaries located in the northern India, north of $16^{\circ} \mathrm{N}$, and lower $\delta^{13} \mathrm{C}_{\mathrm{POC}}$ $\left(-31.4\right.$ to $-28.2 \%$ ) and higher $\delta^{15} \mathrm{~N}_{\mathrm{PN}}(5$ to $10.3 \%$ ) in the estuaries located in the southern India. This is associated with the higher Chl-a in the northern than southern estuaries suggesting that in situ production contributed significantly to the POC pool in the former, whereas terrestrial sources are important in the latter estuaries. The spatial distribution pattern of $\delta^{15} \mathrm{~N}_{\mathrm{PN}}$ is consistent with fertilizer consumption in the Indian subcontinent, which is twice as much in the northern India as in the south whereas ${ }^{13} \mathrm{C}_{\mathrm{POC}}$ suggests that in situ production is a dominant source in the southern and terrestrial sources are important in the northern estuaries. Model studies indicate that 40-90\% (70$90 \%$ ) of organic matter is contributed by $\mathrm{C} 3$ plants (freshwater algae) in the estuaries located in the northern (southern) India.

\section{Chemical Speciation of Trace Metals in the Indian Estuaries}

Estuarine sediment serves as filter for many pollutants between land and sea. With rapid industrialization and economic development, metals are continuing to be introduced to estuarine sediments via several pathways and may potentially result in associated environmental and health problems. Heavy/trace meals are one of the serious pollutants in our natural environment due to their toxicity, persistence and bioaccumulation problems (Chakraborty et al., 2015a; 2015b; 2016a). It has been reported that estuarine sediments are contaminated mostly with heavy/trace metals (Chakraborty et al., 2014a). The environmental problems of estuarine sediment pollution by heavy/ trace metals have received increasing attention in the last few decades in both developing and developed countries throughout the world. It has been widely recognized that heavy/trace metals content in sediments can be useful in assessing the quality of the sediments. Knowledge of distribution and speciation of metals in sediments is necessary for providing a better understanding of their potential impacts at elevated concentrations in environments. Several studies have been carried out to understand the distribution of total metals content in sediments of the Indian estuaries over the last few decades; nevertheless, the information is quite limited for metal distributions and their speciation in the estuarine sediments of India (Chakraborty et al., 2014a). Thus, the speciation and distribution study of metals in sediments has become one of the most important areas of environmental research. 
Different sequential extraction protocols (which can provide information about the distribution of metal associated with different specific solid phases in sediments) and kinetic speciation study (Chakraborty, 2012a; Chakraborty et al., 2014b; 2016b; Sensarma et al., 2016) (which can provide information on the stability of metal-sediment complexes (dynamic or inert) and their dissociation rate constants in sediments) have been used for metal speciation study in the Indian estuarine sediments (Chakraborty et al., 2011;2012b).

Chakraborty et al. (2012c) carried out chemical speciation of lead $(\mathrm{Pb})$ and cadmium $(\mathrm{Cd})$ in the estuarine sediments of Godavari River from the east coast of India. They suggest that concentrations of non-residual and dynamic complexes (which are good indicators of bioavailability) of these toxic metals gradually increase with increasing total metal loading in sediments. Increase in bioavailability of these toxic metals with increasing total metals concentrations in the sediments can be a potential threat to benthic organisms and aquatic biota in the system. The studies indicate that sedimentary organic matter (SOM) is one of the key factors which play a crucial role in controlling speciation of these toxic metals in sediments. However, distribution and speciation of these metals are influenced by their total metal loading and trace metal competitions rather than only SOM content in the sediments.

The intra-annual variations of total sedimentary arsenic and its species during a one year period in the surface sediments of the Godavari estuary (Chakraborty et al., 2012d) indicate that the increasing salinity of overlying water column of sediments may alter the mobility of arsenic complexes in an estuarine system. The higher salt $(\mathrm{NaCl})$ concentrations result in less arsenic adsorption to the sediment due to formation of weak arsenic complexes because of competition from $\mathrm{Cl}^{-}$ions or due to a decrease in inter-particle attraction by the action of $\mathrm{Na}^{+}$. It is suggested that controlled freshwater discharge (from a dam) in the estuary influences the salinity of overlying water and significantly impact on the distribution and speciation of arsenic in the sediments and water column of Godavari estuarine system.

The distribution and speciation of mercury $(\mathrm{Hg})$ in the sediments from Godavari estuary is influenced by the changing physico-chemical parameters of the overlying water column (Chakraborty et al., 2015c). The sediments from the upstream and downstream of the estuary were uncontaminated but the sediments from the middle of the estuary were contaminated by $\mathrm{Hg}$. The concentrations of $\mathrm{Hg}$ became considerably less during the monsoon and post monsoon period. Total $\mathrm{Hg}$ concentrations and its speciation (at the middle of the estuary) were dependent on the salinity of the overlying water column. However, salinity had little or no effect on $\mathrm{Hg}$ association with organic phases in the sediments at downstream. Increasing $\mathrm{pH}$ of the overlying water column corresponded with an increase in the total $\mathrm{Hg}$ content in the sediments. Total sedimentary organic matter in sediments plays an important role in controlling $\mathrm{Hg}$ partitioning in the estuarine system. Uncomplexed $\mathrm{Hg}$ binding ligands were available in the sediments.

The mercury $(\mathrm{Hg})$ distribution in the sediments of the Vembanad Lake (Chakraborty et al., 2015d) suggests that the nature and source of SOM probably control $\mathrm{Hg}$ speciation in the lake system. Speciation study of $\mathrm{Hg}$ suggests that a major part (55-90\%) of the total $\mathrm{Hg}$ was mainly associated with organic phases in the sediment. The variation in concentrations of organic matter bound $\mathrm{Hg}$ with the increasing $\mathrm{Hg}$ / SOM ratio suggests that more $\mathrm{Hg}$ binding sites were available in the sediment from the northern part of the lake but not in the southern part of the lake. Anthropogenic activities were responsible for the higher $\mathrm{Hg}$ content in the sediment collected from the northern part of the lake. It is suggested that the strong affinity of sedimentary total nitrogen (TN) for $\mathrm{Hg}$ is independent of its source. The SOM was found to control $\mathrm{Hg}$ distribution in different size fractions of the estuarine sediment.

Chakraborty et al. (2016a) have shown that the distribution of metals in different binding phases of estuarine sediments provides chemically significant description of metal-sediment interactions. This study describes the influences of ligand field stabilization energy (LFSE), Jahn-Teller effect, and water exchange rate $\left(\mathrm{k}_{\mathrm{w}}\right)$ on metal distribution in different binding phases of estuarine sediments. It was found that Copper had highest affinity for organic binding phases in the studied sediments followed by Nickel and $\mathrm{Pb}$. However, $\mathrm{Pb}$ showed strong association with $\mathrm{Fe} / \mathrm{Mn}$ oxide phases followed by $\mathrm{Ni}$ and $\mathrm{Cu}$. Faster $\mathrm{k}_{-\mathrm{w}}$ of $\mathrm{Cu}$ (II) $\left(1 \times 10^{9} \mathrm{~s}^{-1}\right)$ increased the rate of 
complex formation of $\mathrm{Cu}^{2+}$ ion with ligand in the organic phases. The $\mathrm{Cu}$-ligand (from organic phase) complexes gained extra stability by the Jahn-Teller effect. The combined effects of these two phenomena and high ionic potential increased the association of $\mathrm{Cu}$ with the organic phases of the sediments than $\mathrm{Ni}$ and $\mathrm{Pb}$. The smaller ionic radii of $\mathrm{Ni}^{2+}(0.72 \AA)$ than $\mathrm{Pb}^{2+}(1.20 \AA)$ increase the stability of $\mathrm{Ni}-$ ligand complexes in the organic phase of the sediments. High LFSE of $\mathrm{Ni}(\mathrm{II})$ (compared with $\mathrm{Pb}^{2+}$ ions) also make $\mathrm{Ni}$ organic complexes increasingly stable than $\mathrm{Pb}$. High $\mathrm{k}_{-\mathrm{w}}\left(7 \times 10^{9} \mathrm{~s}^{-1}\right)$ of $\mathrm{Pb}$ did not help it to associate with organic phases in the sediments. The high concentration of $\mathrm{Pb}$ in the $\mathrm{Fe} / \mathrm{Mn}$ oxy-hydroxide binding phase was probably due to co-precipitation of $\mathrm{Pb}^{2+}$ and $\mathrm{Fe}^{3+}$. High surface area or site availability for $\mathrm{Pb}^{2+}$ ion on $\mathrm{Fe}$ oxy-hydroxide phase was probably responsible for the high concentration of $\mathrm{Pb}$ in $\mathrm{Fe} / \mathrm{Mn}$ oxy-hydroxide phase. Increasing concentrations of $\mathrm{Cu}$ in organic phases with the increasing $\mathrm{Cu}$ loading suggest that enough binding sites were available for $\mathrm{Cu}$ in the organic binding phases of the sediments. This study also describes the influence of nature of sedimentary organic carbon (terrestrial and marine derived OC) in controlling these metal distribution and speciation in marine sediment.

Chakraborty et al. (2015b) also established a mechanistic linkage between chemical speciation of $\mathrm{Cu}$ and $\mathrm{Ni}$ and their bioavailability in mangrove ecosystem. Kinetic speciation study was performed to determine the concentrations of labile metalcomplexes and their dissociation rate constants in mangrove sediments from the Zuari estuary, Goa. Concentrations of $\mathrm{Cu}$ and $\mathrm{Ni}$ in the mangrove roots were used as indicators of their bioavailability. It was found that the bioaccumulation of both the metals gradually increased with the increasing concentrations of the labile metal complexes and their dissociation rate constants in the mangrove sediments. This study shows that concentration of labile metal $(\mathrm{Cu}$ and $\mathrm{Ni})$ complexes and their dissociation rate constants in mangrove sediment can be a good indicator of their bioavailability. An attempt was made to establish a mechanistic linkage between the non-residual metal complexes and their bioavailability in the mangrove system (Chakraborty et al., 2015b). The non-residual fractions of $\mathrm{Cu}$ and $\mathrm{Ni}$ were mainly associated with $\mathrm{Fe} / \mathrm{Mn}$ oxyhydroxide and organic phases in the sediments. A part of these metal fractions were bioavailable in the system. These two phases were the major controlling factors for $\mathrm{Ni}$ speciation and their bioavailability in the studied sediments. However, $\mathrm{Cu}$ was found to interact more strongly with the organic phases than $\mathrm{Ni}$ in the mangrove sediments. Organic phases in the mangrove sediments acted as buffer to control the speciation and bioavailability of $\mathrm{Cu}$ in the system (Chakraborty et al. 2015a; 2016b). It has been reported that $\mathrm{Fe} / \mathrm{Mn}$ oxyhydroxide binding phase in estuarine sediment of Zuari river control $\mathrm{Cd}$ bioavailability.

\section{Rock-magnetic Properties of Sediments}

Magnetic parameters of sediments have been used as proxies for the reconstruction of paleoclimate and paleo-rainfall, pollution assessment and identification of provenance and transport pathways. They have also been used as proxy indicators for the identification of methane venting zones. The hydrocarbon seepage (mostly methane gas) often occurs in the region associated with gas hydrate and deeper oil/gas fields. Several investigators have shown enhancement of magnetic susceptibility and other magnetic parameters due to precipitation of authigenic magnetite/maghemite and metastable greigite in the methane/hydrocarbon seep environment, while others have shown the relationship with reduction in the concentration of magnetic iron oxide minerals, authigenic formation of iron sulfides, and occurrence of methane in marine sediments. The Krishna-Godavari (K-G) offshore basin is a proven petroliferous basin of India, and the geoscientific investigations carried out in this basin provided significant information on the nature of the sediments, their physical, chemical and microbial properties. The studies given below indicate the magnetic properties have been used to understand various aspects of sediments.

\section{Diagenesis and Enhanced Methane Flux Event in the Krishna-Godavari Offshore Basin}

The rock magnetic measurements along with SEMEDS and XRD analyses in a sediment core (MD161/ 8) from the K-G offshore basin (Dewangan et al., 2013) showed a zone of reduced magnetic susceptibility (zone 2) where most of the magnetic minerals are dissolved. The enhanced concentration of chromium reducible sulfur (CRS) in this zone suggests an intense pyritization process while isotopically depleted authigenic carbonates indicate 
sulfate reduction via anaerobic oxidation of methane (AOM). Therefore, the dissolution of magnetic minerals is attributed to the $\mathrm{HS}^{-}$released during $\mathrm{AOM}$ that has resulted in the reduction in the magnitude of magnetic parameters. Within zone 2 , a zone of enhanced susceptibility (zone 2a) is observed between 17.68 and $23.6 \mathrm{mbsf}$, and is located beneath the present day sulfate-methane transition zone (SMTZ). The frequency-dependent magnetic susceptibility and low temperature magnetic measurements suggest the abundance of fine grained super-paramagnetic (SP) sized ferrimagnetic particles. The SEM-EDS and XRD analyses show the presence of greigite which occurs in interstices between the pyrite crystals. Such occurrence of greigite in sediments has important implications in the interpretation of paleomagnetic records. The data suggest that the formation of greigite may be related to either paleo-SMTZ or anaerobic oxidation of pyrite. It is unlikely that the formation of greigite can be explained by the downward diffusion of sulfide below the current depth of SMTZ.

Usapkar et al. (2014) investigated the rock magnetic measurements on the topmost sediment samples of 73 gravity cores collected in the KrishnaGodavari (K-G) offshore basin to understand the distribution of magnetic parameters and diagenetic signatures related to upward methane flux. The parameters investigated are susceptibility (c), susceptibility of anhysteric remanent magnetization $\left(\chi_{\mathrm{ARM}}\right)$, saturation isothermal remanent magnetization (SIRM), soft-isothermal remanent magnetization (soft-IRM) and hard-IRM (HIRM). The variation in magnetic parameters in the KG offshore basin fluctuates around the average value $\left(\chi=105 \times 10^{-8}\right.$ $\mathrm{m}^{3} \mathrm{~kg}^{-1}, \chi_{\mathrm{ARM}}=1.22 \times 10^{-5} \mathrm{~m}^{3} \mathrm{~kg}^{-1}, \mathrm{SIRM}=2040$ $\mathrm{x} 10^{-5} \mathrm{Am}^{2} \mathrm{~kg}^{-1}$, soft-IRM $=1807$ and HIRM = 82), except at the location GC-07 where the magnetic parameters $\chi, \chi_{\mathrm{ARM}}$ and SIRM drop to $\sim 1 / 6$ th, $\sim 1 /$ 14 th and $\sim 1 / 8$ th of the average near surface value indicating substantial loss in the concentration of primary magnetic iron oxide minerals. Anomalous low value of $\chi_{\mathrm{ARM}} / \chi$ and $\chi_{\mathrm{ARM}} / \mathrm{SIRM}$ at GC-07 suggests that the magnetic remanence property is governed by coarser pseudo-single domain (PSD) or multidomain (MD) grains. The magnetic parameters were found to be even more depleted at all depths with susceptibility dropping (at $5.2 \mathrm{mbsf}$ ) to $~ 1 / 200$ th of its average near surface value. Interestingly, this core shows a rapid increase in the concentration of dissolved methane from $\sim 0 \mathrm{nM}$ at surface to $\sim 153$ $\mathrm{nM}$ at around $5.2 \mathrm{mbsf}$ where the sulfate concentration is also reduced to zero. The anaerobic oxidation of methane (AOM) and the sulfate methane transition zone (SMTZ) occur between $\sim 4.2$ and 5.2 mbsf based on the present day sulfate concentration profile. The close association between the dissolution of magnetic iron oxide minerals and AOM at GC-07 suggests that the reduced magnetization is primarily due to the release of $\mathrm{HS}^{-}$by AOM. The magnetic iron oxide minerals are dissolved not only at SMTZ but also above the current depth of the SMTZ. It is likely that the methane flux was higher in the past leading to upward shift of the SMTZ, and the HSreleased by AOM facilitated the dissolution of magnetic iron oxide minerals at shallower depths. Alternatively, the $\mathrm{HS}^{-}$diffusing upward from the current depth of SMTZ might have lead to dissolution at shallower depth. Therefore, additional geological/ geochemical investigations are warranted at GC-07 to establish the dissolution mechanism of magnetic iron oxide minerals. The variability in different magnetic parameters within the slope basin and channels shows systematic decrease in the concentration of magnetic minerals and increase in the abundance of stable single domain (SSD) magnetic grains with the water depth. The observed strong correlation between the silt fraction and the magnetic susceptibility for the slope basin and channels suggests that the variation in magnetic parameters is predominantly controlled by the sediment sorting/ transport process as finer particles are deposited in deeper water.

\section{Ore Pollution in Sediments of the Mandovi and Zuari Estuaries}

Iron ore was mined from the banded iron formations of Goa, India, and transported through the Mandovi and Zuari estuaries for six decades until the ban on mining from September 2012. Kessarkar et al. (2015) focused on the environmental magnetic properties of sediments from the catchment area, upstream and downstream of these estuaries, and adjacent shelf during peak mining time. Magnetic susceptibility $\left(\chi_{\mathrm{lf}}\right)$ and saturation isothermal remanent magnetization (SIRM) values of sediments were highest in upstream (catchment area and estuaries), decreased gradually towards downstream (catchment area and estuaries), 
and were lowest on the adjacent shelf. The $\chi_{\mathrm{lf}}$ values of the Mandovi estuary were 2-4 times higher than those in the Zuari. The sediments of these two estuaries after the mining ban showed enrichment of older magnetite and sharp decrease in the SIRM values. Although the input of ore material has been reduced after mining ban, more flushing of estuarine sediments is required for healthier environment.

\section{Provenance and Ore Pollution in the Mandovi Estuary}

Prajith et al. (2015b) investigated rock-magnetic properties of 7 sediment cores along main channel of the Mandovi estuary to record post-depositional changes in sediments and ore pollution. The magnetic susceptibility of the sediments was unusually high in cores from the upper/middle estuary and compare well with that of iron ore. The maximum $\chi_{\mathrm{lf}}$ values in cores from the lower estuary were atleast 6 times lower than in the upper estuary. The $\chi \mathrm{fd} \%$ and $\chi_{\mathrm{ARM}} /$ SIRM of sediments indicated coarse, multi-domain (MD) and pseudo-single domain (PSD) magnetic grains with $<50 \%$ super-paramagnetic (SP) grains in lower sections of cores from the upper/middle estuary and were similar to that of ore material. The cores from lower estuary showed coarse stable single domain (SSD) to fine SSD grains and up to 75\% SP grains at different intervals. S-ratios (44 to 99\%) indicated dominance of hematite and goethite in the upper/middle estuary and magnetite in the lower estuary. Mineralogy parameters indicated hematite and goethite-dominated sediments in the upper/middle estuary and magnetite-dominated sediments in the lower estuary/bay. All cores showed at least two types of sediments, i.e., sediment intervals with low organic carbon (OC), high magnetic concentration and low magnetic grain size ratios alternate with intervals of relatively high OC, low magnetic concentration and high grain size ratios. It is suggested that ore-dominated sediments are interlayered with diagenetically modified sediments. The cores from lower estuary showed higher levels of post-depositional changes and reductive diagenesis at lower horizons, most probably due to strong hydrodynamic conditions. The average $\chi_{\mathrm{lf}}$ and $\mathrm{Fe}$ of top $10 \mathrm{~cm}$ sediment indicates significant iron pollution in the upper/middle estuary and moderate pollution in the lower estuary.

\section{Sediments from the Krishna-Godavari and Mahanadi Basins, Bay of Bengal}

Ichnofossils preserved in marine sedimentary records provide unique information on various activities (feeding, dwelling, excretion etc.) of benthic organisms. Mazumdar et al. (2011) reported faecal pellet-filled tubular (simple and composite) burrow casts from cold seep carbonate layers (16-18 mbsf) deposited at least 46-58 kyr ago in the KrishnaGodavari basin, Bay of Bengal, India. Deposition of these chemosynthetic clam bearing authigenic carbonate sediments with highly depleted carbon stable isotope ratios indicates methane expulsion that resulted in the development of a cold seep ecosystem. Although cold seep communities are extensively reported from the rock record and modern seep sites, hardly any information is available on burrowing activity of the seep biota. This finding opened up a window for future investigation of the ecological significance of such burrows.

Organoclastic degradation and anaerobic oxidation of methane (AOM) are known to influence sulfate, methane and bicarbonate concentrations of sediment pore-waters. Peketi et al. (2012) traced the paleo sulfate-methane transition zones and $\mathrm{H}_{2} \mathrm{~S}$ seepage events in marine sediments, whereas Mazumdar et al. (2012 and 2014) have analyzed the pore-fluid composition of three piston cores (36-39 m long) collected from water depths ranging from 1429 to $1691 \mathrm{~m}$ in the Mahanadi Basin, Bay of Bengal. The linear sulfate concentration profiles and $(\triangle \mathrm{Ca}+$ $\Delta \mathrm{Alk}) / \Delta \mathrm{SO}_{4}{ }^{2-}$ ratios are attributed dominantly to anaerobic oxidation of methane (AOM) induced sulfate consumption. The gas rich layers just below the base of hydrate stability zone (BGHSZ) are the possible source of the enhanced diffusive flux of biogenic methane $\left(\delta^{13} \mathrm{C}_{\mathrm{CH} 4}\right.$ ranging from -99.7 to 106.3\%o VPDB). Occurrences of disseminated gas hydrate in the Mahanadi Basin within the hydrate stability zone (210-220 m thick) supports the link between linear sulfate profile, high rate of AOM and hydrate occurrence.

Mazumdar et al. (2015) also investigated the provenance of sediments by analyzing the bulk major, trace and rare earth element (REE) compositions and clay minerals from the cores collected on board JOIDES Resolution and Marion Dufresne in the 
Krishna-Godavari and Mahanadi offshore basins. The results show that the Mahanadi sediments are primarily derived from the felsic rocks belonging to the late Archean-early Proterozoic peninsular gneissic complexes, whereas the Krishna-Godavari sediments are derived from the mixing of late Archean-early Proterozoic peninsular gneissic complexes and Late Cretaceous Deccan basalt sources. The sediment geochemistry enables distinction of specific contributing sources, which could potentially be related to modern climatic and geomorphological conditions.

Joshi et al. (2014) reported carbon isotope excursions in planktic and benthic foraminifera in a core (MD161-8) from the Krishna-Godavari (K-G) Basin, Bay of Bengal. The most negative $\delta^{13} \mathrm{C}$ spikes are recorded during the marine isotope stages MIS-4 and at the transition of MIS-5 to 4 . Occurrence of highly $\delta^{13} \mathrm{C}$ depleted (average $\delta^{13} \mathrm{C}=-48 \pm 2.4 \%$ o VPDB) authigenic high magnesian calcite are also reported within this time window from the core MD161-8. In the present work an unequivocal explanation for the observed $\delta^{13} \mathrm{C}$ depletion in the marine planktic and benthic foraminifera is difficult to achieve solely from the optical/electron microscopyor C-O stable isotope ratio analyses due to possible influence of diagenetic alteration. The negative $\delta^{13} \mathrm{C}$ excursions were attributed to the observed episodic methane expulsion events, that were inferred from earlier reports on the occurrence chemosynthetic bivalves and Mo concentration anomaly to the destabilization of the base of gas hydrate stability zone (BGHSZ). Sea level drop and shale tectonics induced focused fluid flow are the two possible causes of hydrate destabilization discussed here. Shaletectonics were possibly responsible for creating fault systems which acted as the conduit for gas flow through the sediment column and subsequent seepage. Shale and salt tectonics in the passive

\section{References}

Bardhan P, Karapurkar S G, Shenoy D M, Kurian S, Sarkar A, Maya M V, Naik H, Varik S and Naqvi S W A (2015) Carbon and nitrogen isotopic composition of suspended particulate organic matter in Zuariestuary, west coast of India Journal of Marine Systems 141 90-97

Chakraborty P, Babu P R and Sarma V V (2011) A multi-method approach for the study of lanthanum speciation in coastal continental margins being a globally observed phenomenon, its role as an important driving force for enhanced methane emission needs detailed investigation to understand the climatic perturbations through geologic time. Additional evidence of methane emission from site MD161-15 further supports the link between shale tectonics and methane emission.

\section{Genesis of Lime Muds on the Western Shelf of India}

Rao et al. (2012) investigated the genesis of lime muds on the western shelf of India. Two sediment types were found in five gravity cores collected from water depths between $56 \mathrm{~m}$ and $121 \mathrm{~m}$ along the northwestern continental margin of India: lime muds were abundant in the lower section while siliciclastic sediments dominated the upper section. Lime muddominated sediments in shelf cores contained 60\%$75 \%$ carbonate, $0.3 \%-0.6 \% \mathrm{Sr}$ and terrigenous minerals, whereas those at the shelf break were found to have $>90 \%$ carbonate, $0.6 \%-0.8 \% \mathrm{Sr}$ and traces of terrigenous minerals. Aragonite needles showing blunt edges, jointed needles and needles wrapped in smooth aragonite cement were found to be common. Stable (O and $\mathrm{C})$ isotopes of lime mud indicate a potentially freshwater contribution for shelf cores and purely marine contribution for those at the shelf break. Calibrated radiocarbon ages of the lime muds ranged from $17.6-11.9 \mathrm{ka}$ in different cores. The results reported here suggest that the lime muds in the shallow shelf are probably reworked from the Gulf of Kachchh, whereas those at the shelf break were biodetrital, initially formed on the carbonate platform during low stands of sea level and then exported. The change in lime mud-dominated to siliciclasticdominated sediments in the cores may be due to climate change and rapid rise in sea level during the early Holocene.

and estuarine sediments Journal of Geochemical Exploration $110225-231$

Chakraborty P (2012a) Speciation of Co, Ni and Cu in the coastal and estuarine sediments: Some fundamental characteristics Journal of Geochemical Exploration 115 13-23

Chakraborty P, Babu P R and Sarma V V (2012b) A new spectrofluorometric method for the determination of total arsenic in sediments and its application to kinetic speciation 
International Journal of Environmental Analytical Chemistry 92 133-147

Chakraborty P, Babu P R and Sarma V V (2012c) A study of lead and cadmium speciation in some estuarine and coastal sediments Chemical Geology 294 217-225

Chakraborty P, Jayachandran S, Babu P V R, Karri S, Tyadi P, Yao K M, Brij Mohan Sharma (2012d) Intra-annual variations of arsenic totals and species in tropical estuary surface sediments Chemical Geology 322 172-180

Chakraborty P, Ramteke D, Chakraborty S and Nath B N (2014a) Changes in metal contamination levels in estuarine sediments around India-an assessment Marine Pollution Bulletin 78 $15-25$

Chakraborty P, Babu P R, Vudamala K, Ramteke D and Chennuri $\mathrm{K}$ (2014b) Mercury speciation in coastal sediments from the central east coast of India by modified BCR method Marine Pollution Bulletin 81 282-288

Chakraborty P, Ramteke D, Chakraborty S, Chennuri K and Bardhan P (2015a) Relationship between the lability of sediment-bound $\mathrm{Cd}$ and its bioaccumulation in edible oyster Marine Pollution Bulletin 100 344-351

Chakraborty P, Ramteke D and Chakraborty S (2015b). Geochemical partitioning of $\mathrm{Cu}$ and $\mathrm{Ni}$ in mangrove sediments: Relationships with their bioavailability Marine Pollution Bulletin 93 194-201

Chakraborty P and Babu P R (2015c) Environmental controls on the speciation and distribution of mercury in surface sediments of a tropical estuary, India Marine Pollution Bulletin 95 350-357

Chakraborty P, Sarkar A, Vudamala K, Naik R and Nath B N (2015d) Organic matter - a key factor in controlling mercury distribution in estuarine sediment Marine Chemistry 173 302-309

Chakraborty P, Ramteke D, Gadi S D and Bardhan P (2016a) Linkage between speciation of $\mathrm{Cd}$ in mangrove sediment and its bioaccumulation in total soft tissue of oyster from the west coast of India Marine Pollution Bulletindoi 106 274-282 10.1016/j.marpolbul.2015.12.025

Chakraborty P, Chakraborty S, Vudamala K, Sarkar A and Nath B $\mathrm{N}$ (2016b) Partitioning of metals in different binding phases of tropical estuarine sediments: importance of metal chemistry Environmental Science and Pollution Research $233450-3462$

Dewangan P, Basavaiah N, Badesab F K, Usapkar A, Mazumdar A, Joshi R and Ramprasad T (2013) Diagenesis of magnetic minerals in a gas hydrate/cold seep

environment off the Krishna-Godavari basin, Bay of Bengal Marine Geology 340 57-70
Joshi R K, Mazumdar A, Peketi A, Ramamurty P B, Naik B G, Kocherla M, Carvalho M A, Mahalakshmi P, Dewangan P and Ramana M V (2014) Gas hydrate destabilization and methane release events in the Krishna-Godavari basin, Bay of Bengal Marine Petroleum Geology 58 476-489

Kessarkar P M, Shynu R, Rao V Purnachandra, Feng Chong, Tanuja N and Jing Zhang (2013) Geochemistry of the suspended sediment in the estuaries of the Mandovi and Zuari rivers, central west coast of India Environmental Monitoring and Assessment 185 4461-4480

Kessarkar P M, Suja S, Sudeesh V, Srivastava S, Rao V and Purnachandra (2015) Iron ore pollution in Mandovi and Zuari estuarine sediments and its fate after mining ban Environmental Monitoring and Assessment 187 572-588

Krishna M S, Naidu S A, Subbaiah Ch V, Gawade L, Sarma V V S S, Reddy and N P C (2015) Sources, Distribution and Preservation of Organic Matter in a Tropical Estuary (Godavari, India) Estuaries and Coasts 38 1032-1047

Maya M V, Soares M A, Agnihotri R, Pratihary A K, Karapurkar S, Naik H, Naqvi and S W A (2011) Variations in some environmental characteristics including $\mathrm{C}$ and $\mathrm{N}$ stable isotopic composition of suspended organic matter in the Mandovi Estuary Environmental Monitoring and Assessment 175 501-517

Mazumdar A, Joshi R K, Peketi A and Kocherla M (2011) Occurrence of faecal pellet-filled simple and composite burrows in cold seep carbonates: A glimpse of a complex benthic ecosystem Martine Geology 289 117-121

Mazumdar A, Joao H M, Peketi A, Dewangan P, Kocherla M, Joshi R K and Ramprasad T (2012) Geochemical and geological constraints on the composition of marine sediment pore fluid: Possible link to gas hydrate deposits Marine and Petroleum Geology 38 35-52

Mazumdar A, Peketi A, Joao H M, Dewangan P and Ramprasad T (2014) Pore-water chemistry of sediment cores off Mahanadi Basin, Bay of Bengal: Possible link to deep seated methane hydrate deposit Marine and Petroleum Geology 49 162-175

Mazumdar A, Kocherla M, Carvalho M A, Peketi A, Joshi R K, Mahalaxmi P, Joao H M and Jisha R (2015) Geochemical characterization of the Krishna-Godavari and Mahanadi offshore basin (Bay of Bengal) sediments: A comparative study of provenance Marine and Petroleum Geology 60 8-33

Peketi A, Mazumdar A, Joshi R K, Patil D J, Srinivas P L and Dayal A M (2012) Tracing the Paleo sulfate-methane transition zones and $\mathrm{H} 2 \mathrm{~S}$ seepage events in marine sediments: An application of C-S-Mo systematic 
Geochemistry, Geophysics and Geosystems 13 Q10007, $11 \mathrm{pp}$

Prajith A, Rao V Purnachandra and Kessarkar P M (2015a) Controls on the distribution and fractionation of yttrium and rare earth elements in core sediments from the Mandovi estuary, western India Continental Shelf Research 92 5971

Prajith A, Rao V Purnachandra and Kessarkar P M (2015b) Magnetic properties of sediments in cores from the Mandovi estuary, western India: inferences on provenance and pollution Marine Pollution Bulletin 99 338-345

Prajith A, Rao V Purnachandra and Chakraborty P (2016). Distribution, provenance and early diagenesis of major and trace metals in sediment cores from the Mandovi estuary, western India Estuarine Coastal and Shelf Science 170 173-185

Rao V Purnachandra, Shynu R, Kessarkar P M, Sundar D, Michael G S, Narvekar T, Blossom V and Mehra P (2011) Suspended sediment dynamics on a seasonal scale in the Mandovi and Zuariestuatries, central west coast of India Estuarine, Coastal and Shelf Science 91 78-86

Rao V Purnachandra, Kumar A A, Naqvi S W A, Chivas A R, Sekar B and Kessarkar P M (2012) Lime muds and their genesis off Northwestern India during the late Quaternary Journal of Earth System Science 121 769-779

Rao V Purnachandra, Shynu R, Singh S K, Naqvi S W A and Kessarkar P M (2015) Mineralogy and Sr-Nd isotopes of SPM and sediments from the Mandovi-Zuari estuaries: influence of weathering and anthropogenic contribution Estuarine, Coastal and Shelf Science 156 103-115

Sarma V V S S, Arya J , Subbaiah Ch V, Naidu S A, Gawade L, Praveen Kumar P and Reddy N P C (2012) Stable isotopes of carbon and nitrogen in suspended matter and sediments from the Godavari estuary Journal of Oceanography 68 307-319

Sarma V V S S, Krishna M S, Prasad V R, Kumar B S K, Naidu S A, Rao G D, Viswanadham R, Sridevi T, Kumar P P and Reddy N P C (2014) Distribution and sources of particulate organic matter in the Indian monsoonal estuaries during monsoon J Geophysical Research, Biogeosciences 119 2095-2111
Sensarma S, Chakraborty P, Banerjee R and Mukhopadhyay S (2016) Geochemical fractionation of $\mathrm{Ni}, \mathrm{Cu}$ and $\mathrm{Pb}$ in the deep sea sediments from the Central Indian Ocean Basin: An insight into the mechanism of metal enrichment in sediment Chemie der Erde-Geochemistry 76 39-48 doi: 10.1016/j.chemer.2015.10.002

Shynu R, Rao V Purnachandra Kessarkar P M and Rao T G (2011) Rare earth elements in suspended and bottom sediments of the Mandovi estuary, central west coast of India: Influence of mining Estuarine, Coastal and Shelf Science 94 355-368

Shynu R, Rao V Purnachandra, Kessarkar P M and Rao T G (2012) Temporal and spatial variability of trace metals in suspended matter of the Mandovi estuary, central west coast of India Environmental Earth Sciences 65 725-739

Shynu R, Rao V Purnachandra, Parthiban G, Balakrishnan S, Narvekar T and Kessarkar P M (2013) REE in suspended particulate matter and sediment of the Zuari estuary and adjacent shelf, western India: influence of mining and estuarine turbidity Marine Geology 346 326-342

Shynu R, Rao V Purnachandra, Sarma V S S S, Kessarkar P M and Mani Murali R (2015) Sources and fate of organic matter in suspended and bottom sediments of the Mandovi and Zuari estuaries, western India Current Science $\mathbf{1 0 8}$ 226-238

Suja S, Kessarkar P M, Shynu R, Rao and V Purnachandra (2016) Spatial distribution of suspended particulate matter in the Mandovi and Zuari estuaries: inferences on the estuarine turbidity maximum Current Science (in Press)

Volvoikar S P, Nayak G N, Mazumdar A and Peketi A (2014) Reconstruction of depositional environment of a tropical estuary and response of $\delta^{13} \mathrm{C}_{\text {org }}$ and TOC/TN signatures to changing environmental conditions Estuarine, Coastal and Shelf Science 139 137-147

Usapkar A, Dewangan P, Kocherla K, Ramprasad T, Mazumdar A and Ramana M V (2014) Enhanced methane flux event and sediment dispersal pattern in the Krishna-Godavari offshore basin: Evidences from rock magnetic techniques Marine and Petroleum Geology 58 461-475. 